\title{
A Regretful Journey Home: Albanian Return Migration in the Wake of the Global Financial Crisis of 2008
}

\author{
Elida Cena $^{1} \cdot$ Derek Heim $^{2}$
}

Accepted: 25 May 2021/Published online: 23 June 2021

(C) Crown 2021

\begin{abstract}
Despite occurring almost a decade ago, the effects of the 2008 global financial crisis continue to influence the lives of many people today. Intra-European migration literature, for example, suggests that migration patterns were reshaped in its aftermath and emerging literature details mobilities and experiences of migrants in destination societies post-crisis. To date, less research documents the experiences of individuals who, in the wake of the crisis, were forced to abandon their migratory endeavours and had to navigate returning to their country of origin in a particularly challenging socioeconomic context. Utilising in-depth interviews and family case studies with purposively recruited Albanian return migrants who had lived in Greece and Italy pre-crisis, the current study highlights how conditions in both destination and origin countries impacted return experiences. Findings illustrate an adverse interplay of circumstances that led to the unsettled return and portray a perturbing fluidity in the lives of return migrants who appear overcome by a sense of 'double failure' with regard to both outward migration and subsequent return to their country of origin.
\end{abstract}

Keywords Return migration · Global financial crisis · Post-return experiences · Albania • Origin country $\cdot$ Homecomings

Elida Cena

E.Cena@qub.ac.uk

Derek Heim

Heimd@edgehill.ac.uk

1 School of Psychology, Queen's University Belfast, David Keir Bldg, 18-30 Malone Rd, Belfast BT9 5BN, UK

2 Department of Psychology, Edge Hill University, Lancashire, Ormskirk L39 4QP, UK 


\section{Introduction}

The role of return migration in shaping the economies of the home countries to which people return has gained considerable attention in the literature which recognises migrants as important sources of change. As such, the migration literature has long documented that return migrants can make to the development of the home economies (McCormick \& Wahba, 2001). From a transnational perspective, individuals intending to return prepare for this by maintaining regular contact with the home country (Duval, 2004) and sustaining social connections with the people (Reynolds, 2008) and through the mobilisation of the human and financial resources, usually in the form of financial savings (Borjas and Bratsberg 1996; Cassarino, 2004). In this way, migrants accumulate human and monetary capital and skills that are beneficial for occupational mobility and entrepreneurship upon return (Black \& Castaldo, 2009; De Haas, 2005; Grabowska \& Jastrzebowska, 2019; Mayer et al., 2015; Sinatti, 2018; Wang \& Yang, 2013). This literature has yielded valuable insights into the benefits of human capital acquired during migration (Cassarino, 2004) and in portraying migrants as potential investors and agents of economic development in the origin country. Nevertheless, this literature has focused on successful return migration, and more recent contributions have highlighted that return migration is not a homogenous process and that capital formation does not always guarantee economic mobility upon return (Hagan \& Wassink, 2020).

Despite the optimistic expectations of successful economic migrants, return experiences vary as a function of differing reasons and intentions to return to the origin countries which may overlap (Cassarino, 2004; Baser \& Toivanen, 2019). The multiple types of return reflect that even though migrants may prepare, the return can be a complicated process and that experiences of returnees are shaped by broader factors which involve the circumstances in the destination country as well as the economic and political conditions in the origin country (Cassarino, 2008). While these factors are important for understanding various experiences of returnees, migrants are often affected by volatile economic situations disproportionately (Beets and Willekens 2009) and the literature is limited on the matter explaining return migration which occurred following the global financial crisis of 2008 (hereafter 'financial crisis'). The recent financial crisis has revived an interest in the return migration-development nexus, particularly for Central and Eastern European countries which benefitted from a free mobility intra-European migration (Coniglio \& Brzozowski, 2018).

Existing research concerning migration during the financial crisis conducted with migrants from EU post-accession countries suggests that the crisis profoundly changed migration flows by increasing intra-European movements (Bygnes \& Erdal, 2017; Zaiceva \& Zimmermann, 2016). As a response to manage the effects of the economic downturn, Europe saw no recorded large-scale returns because origin countries for many of the migrants in Western Europe were suffering from recessions and the social safety net was perceived to be stronger than in the origin countries (IOM, 2009; Lafleur $\&$ Stanek, 2016). This research has been particularly useful in showing the way patterns of migration flows have changed as a consequence of the economic downturn by decreasing out-migration flows and facilitating more circular form migration. However, there is a lack of consideration - and voice given to these casualties of the economic crisis - with regard to the experiences of migrants who, due to adverse circumstances in 
the country of destination, felt compelled to return to their countries of origin. Building on this, the aim of this paper is to examine return migration following the major economic upheavals ensuing from the financial crisis by focusing on the experiences of Albanian migrants who had prematurely decided to return to the home country.

Our findings show that decisions to return were undertaken in the face of economic adversity. The circumstances of return, in the present study, interact with economic conditions and lack of occupational mobility with participants portraying the return as a difficult and regretful journey home. We find that these conditions and determinants shape individuals' socio-economic prospects in different ways, with returnees who possess less adaptable skills relevant to the local context being less able to engage in economic activities. Return migrant resettlement is therefore shaped by the local environments as well as a lack of preparation undermining adapting to the local labour market. The findings suggest that experiences of return are impacted by the ability to remain transnationally mobile and economically connected with the previous country to afford a sense of security and enable returnees to overcome current economic challenges and adverse impacts on their plans for the future. Lack of satisfaction with the return experiences and continuing identification with the previous country affects respondents' ability to forge a sense of belonging with the home country.

With the above in mind, the remainder of this article begins by situating the current work within relevant theoretical frameworks that analyse return motivations and experiences. It then outlines the qualitative methodology used to collect data and justifies the choice of analysis. In the results section, we first present an analysis of respondents' perspectives on the economic and social circumstances under which the return took place and consider differences in return preparedness between participants. Second, we show how return migrants re-evaluate and reconceptualise their initial migration experience in light of return outcomes. Third, we consider how returnees' negative experiences and movement restrictions combine to impact their plans for the future. Finally, in the discussion, we situate current findings in the wider theoretical literature.

\section{The Economic and Social Impact on Return Migration}

\section{Economical Approaches in Return Migration}

Neoclassical Economics and the New Economics of Migration understand return migration experiences by examining intentions for return and considering how these are shaped by contextual influences (De Haas \& Fokkema, 2011; van Meeteren et al., 2014). The return has also been theorized in terms of a decision process that is partly shaped by the conditions in the destination and origin countries, categorised as 'pull' and 'push' factors (King, 2000). Economic development in a country of origin or better wages are, for instance, categorised as the 'pull' factors, whereas issues such as an economic downturn in the country to which migrants had emigrated are considered 'push' factors. In this light, some approaches have conceptualised return migration as a 'failure', while others proffer a more positive perspective that, owing to accomplishments in destination countries, considers return a 'successful' outcome. Neoclassical approaches have tended to focus on the logic underpinning economic decisions, such as 
the cost-benefit calculations, and suggest that return migration occurs as a result of economic or social migration failures (Sjaasaad, 1962; Constant \& Massey, 2002). New Economics of Labour Migration (NELM), on the other hand, places emphasis on households rather than individuals and views return as a natural outcome of a successful migration experience and as the final stage of a predetermined plan (Constant \& Massey, 2002). Another strand of the literature with a focus on determinants of returning views return migration as an unplanned decision which is prompted by insufficient information about the host country relating to economic opportunities or inability to meet saving targets in the host country (Borjas and Bratsberg 1996). Other studies further document various return migration motives and illustrate the effect of income and wages in the host country to explain return migration (Bijward 2010). These analyses suggest that individuals with lower income followed as well as top earners show the highest propensity to return (Bijward and Wabha 2019).

\section{Sociological Approaches}

\section{Transnationalism}

Addressing wider socio-economic, political and cultural conditions, transnationalism emphasises the importance of considering connectivity across nations (Portes et al. 1999). Transnational practices, according to this approach, are a feature of contemporary international migration that encompass economic and social activities and place emphasis on the importance of linkages that transcend borders. In this way, research suggests that migrants' engagement with transnational activities with the home country can increase return intentions (Groenewold and De Valk, 2017). The transnationalism approach highlights the significance of social remittances (i.e. the social capital and skills that returnees have accumulated during migration) as important determinants of migrants' economic mobility (Hagan and Wassink, 2020), whereby ideas, behaviours and other aspects of social life are transferred within transnational spaces (Levitt 1998). In support of these ideas and compared with migrants with limited access to transnational mobility, fostering transnational practices and maintaining networks with the destination country have been found to be associated with positive post-return experiences (De Bree et al. 2010; Van Meeteren et al. 2014). This work and other contributions (Faist, 2008; van Houte et al. 2015; Itzigsohn and Saucedo, 2002) also emphasise that transnational activities are not available to all and can be limited to certain groups of migrants based on their socio-economic position in the destination countries.

\section{Structural Approaches}

Relatedly, the seminal contribution by Cassarino (2004) highlights the role of structural conditions impacting the degree to which skills and social capital are transferable to the local context. The willingness to return and the degree of preparation (e.g. gathering of the financial means, information and social networks), according to Cassarino (2004), are also important considerations when seeking to explain post-return experiences. According to this model and supporting empirical findings, higher levels of preparedness (e.g. willingness to return, having better information about the conditions in the country of origin) tend to be associated with more positive outcomes (Koser and 
Kuschminder 2015; Van Meeteren et al. 2014). However, the model does not place an explicit emphasis on the opportunities return migrants can take advantage of in the home economies (Hagan and Wassink 2020). Returnees to Poland during the financial crisis, for example, often experienced hardship when re-entering the labour market, and skills accumulated during migration were not always deployable back home (Coniglio and Brzozowski, 2018). Such obstacles can be associated with unequal wage structures in the origin countries and wider economic conditions, which can hinder the return process and the extent to which specific skills can be transferred (Hagan and Wassink 2020). In turn, challenges in re-entering the labour market and finding employment serve wider functions to migrants than providing a source of income. Challenges experienced in work-life can in turn have a negative impact on migrants' well-being and hinder their socio-cultural adaptation (Aycan and Berry 1996; Yijälä and Luoma 2019). In our study, we build on these findings and theoretical frameworks to examine the extent to which Albanians who return under difficult economic circumstances are able to capitalise on skills acquired abroad and their level of preparedness. In this context, we consider transnational engagement and mobility as influences on the return process.

\section{The Current Study in Context}

Albanian emigration represents a unique case in international migration due to the significant size of the population outflow and the type of migration that is almost exclusively directed towards two destination countries, Greece and Italy (Vullnetari 2013). Following the collapse of the communist regime, which had largely isolated the country for 45 years, a series of mass-migrations occurred in the 1990s. Albanian migration was therefore characterised by both 'push and pull' factors as a result of political and socio-economic crises which engulfed the country (Carletto et al. 2006). An estimated 500,000 Albanians - more than $20 \%$ of the population at the time-were reported to live in Greece and a further 200,000 lived in Italy before the 2008 financial crisis (King 2007). The migratory journey of Albanians in both countries was initially characterised by irregular migration which later on moved towards regular migration. While Italy was more prepared for migration flows of Albanians, in Greece, migratory movements of Albanians tended to be irregular and more circular and temporary, involving semi-skilled, low-skilled or unskilled male migrants (Maroukis and Gemi 2011). Employment was largely shaped by the socio-economic structures and informality, giving way to illegal employment activities. The main sectors of employment were construction, agriculture, tourism and catering.

Throughout 1990s and in early 2000s, both Greece and Italy undertook a series of regularization procedures with the aim of legalizing undocumented migrants. Migration legislative frameworks led to significant changes to the ratio of regular to irregular migration with the number of regular migrants increasing significantly since 1999 in both countries (Barjaba 2018). The undertaken reforms were introduced in different stages and included measures such as the right to obtain and renew residence permits and consolidate migrants' legal status within the host countries. The process to obtain rights of abode was particularly complex in Greece where permits to stay were granted based on the contributions made to the Greek welfare system and the naturalization 
process applied mostly to people who could prove their Greek origins (Triandafyllidou et al. 2013). With the introduction of regularisations, a pattern of relative economic stability was evidenced as migrants moved from agricultural work towards semi-skilled work and small business enterprises in both countries (Barjaba \& King, 2005; Lyberaki \& Maroukis, 2005). Even though these legal frameworks resulted in occupational improvement of Albanian migrants in the local communities, there was still considerable inequality and lack of economic integration. For example, data from 2007 on wage differences in Greece indicate that an Albanian man earned 36\% less than a native male worker (Triandafyllidou and Lazarescu 2009). Also, the lack of social security in Greece hampered Albanian migrants to gain access to unemployment benefits, highlighting that only $57 \%$ of unemployed Albanian migrants benefited from unemployment benefits in Greece and Italy (Triandafyllidou and Lazarescu 2009). Migrants benefitted from access to health care services and retirement benefits with signs of upward occupational and social mobility (Barjaba and King 2005; Lyberaki and Maroukis 2005). The ratio of regular to irregular migrants in Italy (3:1) was double the comparable ratio of that in Greece (1.5-1), which reflects the relatively quicker integration and upward socio-economic mobility of Albanian migrants in Italy (Barjaba 2018).

Growing unemployment during the economic recession in Greece caused economic instability for Albanian migrants which impacted deeply both formal and informal labour migrants adversely (Adamczyk 2016). To illustrate, between 2008 and 2011, the unemployment rate of Albanians in Greece increased from 6 to 21\% (Cavounidis 2018) and by $2011,40 \%$ of the Albanian migrants in Greece lost their jobs (Hausman and Nedelkoska, 2018) which was reflected in the flow of remittances to Albania which decreased markedly from 2008 to 2014 (USD 1450 million to USD 1150 million - a drop from 11 to $8.5 \%$ of Albanian GDP, respectively; see Hausman and Nedelkoska, 2018). In turn, the high unemployment rates led to regular migrants losing their jobs and an inability to contribute to the welfare system which made it difficult to obtain residency rights in Greece (Gemi, 2014). As a result of unemployment, large number of people lost their legal residence status which led to Albanians returning to Albania in order to seek employment opportunities there (Adamczyk 2016). The return was also propelled by the regulations implemented by the respective governments during 20112013 that aimed to strengthen anti-immigration legislation and closed the boarders in fear of a large influx of undocumented immigrants which, particularly in Greece, led to the deportation of immigrants to Albania (Adamczyk 2016; Caponio and Cappiali 2018). The economic upheaval following the financial crisis, in this way, reshaped existing migration flows which resulted in decreased migratory movements and spurred a large return migration (Zaiceva and Zimmermann 2016). Countries such as Greece and Italy that were among the hardest hit in Europe experienced high levels of unemployment which disproportionately affected immigrant populations (Lafleur and Stanek 2016). The Census data on return migration in Albania suggest that the number of return migrants increased sharply during the period 2009-2013 with a total of 133,544 (INSTAT and IOM 2013). The returnees were relatively young and typically male $(73 \%)$ and aged between 25 and 29 years. The survey shows that $94 \%$ of the migrants returned to Albania voluntarily and the rest were forced to return. The primary reasons for return were loss of jobs in the migrating country and longing for the home country, followed by reasons such as acquiring better job opportunities in Albania or 
family obligations. Data related to the destination country from where Albanian migrants return show that the majority of returnees came from Greece $(70.8 \%)$ followed by Italy (23.7\%). Statistics from INSTAT and IOM (2013) indicate that upon return nearly $50 \%$ of return migrants in Albania were unemployed.

Return migration in Albania is not a new phenomenon; however, existing research has predominantly focused on the impact of return migration in the economic development of the home country (Germenji and Milo, 2009; Hausman and Nedelkoska, 2018; Kule et al. 1999; Piracha and Vadean 2010). In this way, studies indicate that migration experiences can increase migrants' capacity for entrepreneurship upon returning to Albania (Piracha and Vadean 2010) and that returnees who become selfemployed are able to transfer human capital into the home economies (Germenji and Milo 2009). The propensity to set up a business, for example, appears to be highest among return migrants who had a longer period of migration (Kule et al. 1999), and it is more likely among migrants returning from countries other than Greece (such as Italy or the UK) (Kilic et al., 2009). However, unskilled returnees are more likely to become self-employed owing to a lack of employment opportunities in the home country Piracha and Vadean 2010) which highlights the way conditions in the home country impact the reintegration process of return migrants. To understand the economic situation of Albania in the wake of financial crisis, statistical data based on reports of UNDP indicate that until 2010, Albania was initially less adversely affected by the global economic crisis than other countries. This was attributed to fiscal policies and the close supervision of the banking sector although there is evidence that economic difficulties in Albania arose pre-crisis (UNDP 2016). By 2012, however, Albania's GDP growth reached its lowest level in a decade (0.6\%; BTI, 2014) and the economic downturn impacted the labour market with a fall in employment and associated family income. Existing research focussing on Albania during this period has ascertained that return migrants from Greece were comparatively more likely to be entrepreneurs, often had higher wages and were more likely to employ locals (Hausman and Nedelkoska, 2018). Mirroring similar economically focussed research, this quantitative work was partly based on wage comparisons with non-migrants and complementary research is needed to consider these findings in the broader social context of return (Hagan and Wassink, 2020). Other researches with an explicit focus on this period in Albania are scarce and have, for example, centred on the educational, well-being and belonging challenges of children (Cena et al., 2018).

\section{Methodology}

The principle method of data collection for this study was semi-structured interviewing with return migrants in Albania. All interviews were conducted with participants over 18 years of age who had been migrants in Greece and Italy. The data were collected in two cities, in Tirana (the capital city) and Fier, from May 2015 through July 2015. We acknowledge that these two cities do not represent the Albanian return migrant population as a whole, and these two cities were selected strategically based on (i) having the highest concentration of return migrants in the country (see INSTAT and IOM 2013) and (ii) as two economically contrasting cities, with the capital being the 
engine of the economy in the country and enabling comparatively greater socioeconomic possibilities (Pojani 2010).

We conducted 21 in-depth interviews and supplemented these with three family case studies that were conducted in respondents' homes as well as one focus group $(n=7)$. Purposive snowballing sampling methods were employed to reach a varied set of respondents. We aimed to recruit a sample with diverse backgrounds in terms of age, gender, place of return, period of migration and length of residing in the destination country and in Albania upon the return. To reduce the bias of the recruitment method, we ensured that participants who took part in in-depth interviews did not feature in the focus group interview or family case studies. Sixty-six percent of respondents had returned from Greece and 34\% from Italy. Participants were aged between 30 and 50 years, and their mean age was 38.2 years $(\mathrm{SD}=6.2)$ and all of them had families. Some of the families $(n=5)$ who had returned were physically separated with one or two members remaining in Greece or Albania, respectively. The average time respondents lived abroad was 12.1 years $(\mathrm{SD}=5.6)$ and the average length of time being back in Albania was 3.4 years $(\mathrm{SD}=1.8)$. Seventy-one percent of respondents were recruited in Tirana and 29\% were recruited in Fier. The sample broadly reflects the existing figures and data of the return migrant population in Albania post-2008 (INSTAT and IOM 2013). Interviews with a subset of participants were conducted in June 2015. Because of the small sample and the sampling method, we should not consider this study and its findings representative of the whole Albanian return migration population. The sample therefore is unlikely to represent the entire groups of migrants, particularly those living in rural areas. The purpose is rather to offer depth and richness of data for a limited number of cases of a group of return migrants in much need of attention and our combined qualitative methods generated rich data.

Following ethical approval, semi-structured interviews were conducted face to face, in different locations such as cafes. Interviews were conducted by one of the researchers in Albanian who then transcribed the interview and translated them into English. The semi-structured interview schedule gauged the circumstances which led to the return and the social and economic experiences and problems experienced following the return as well as identification with the homeland. Questions were designed to be open-ended and to capture experiences in the destination society and the circumstances which led to the return decision. They also focused on participants' level of preparedness for the return and the challenges faced upon return. Towards the end of the interviews, which lasted between 25 and $110 \mathrm{~min}$, future plans of the respondents were ascertained. All names have been changed to help ensure participants' anonymity. Follow-up interviews with ten individual respondents and the three family case studies were undertaken in May and June 2016, 1 year after the first wave of data collection.

Analytically, we used a narrative approach which considers stories as knowledge and communicates the way individuals derive meaning out of their experiences through spoken words, its depth and texture (Earthy and Cronin 2008). Narrative analysis takes into account the content by referring to the categories and themes arising from the data as well as the textual and structural characteristics of the story to examine the performative aspects of participants' self-portrayals (Bamberg, 2012). In analysing data, a deductive and inductive form of analysis was completed concurrently. The analysis of narratives was initially guided by predetermined concepts and theoretical frameworks in research on return migration with a focus on migrant preparedness, 
circumstances of return, voluntariness, belonging, (dis)identification with the home country and transnational movements. Nevertheless, researchers remained open to the data to uncover new experiences that could be unique to this particular group returning under circumstances which were novel in the literature at the time. Our main unit of analysis was the content, for which we followed a thematic narrative analysis approach by identifying themes in the data through considering both surface and latent content within the story and analysing emergent themes across cases. Data analysis was facilitated by the use of NVivo.

\section{Findings}

\section{Pressured Decisions to Return}

Experiences of return migrant families reflected the challenges posed by the 2008 economic crisis and having experienced an undesired return. For many respondents, returning to the homeland during this period resulted in concomitant unemployment and economic difficulties. Almost all respondents had lost their jobs in Greece and Italy as the economy, particularly in Greece, had deteriorated into a deep recession. The majority said they did not wish to return to Albania and had delayed returning until they had exhausted all the possibilities in their previous host countries. Many respondents indicated that, as the crisis wore on, they were left with no choice other than to return. Participants spoke about how they had used up their savings in the wake of the crisis and that the resulting financial difficulties were the primary reason for returning.

It appeared that narratives were shaped by the extent to which respondents felt informed about the local conditions in Albania. As such, the majority of participants in this study could not visit Albania often and lacked information about local conditions. Narratives of these individuals were characterised by 'illusionary expectations' about opportunities afforded by returning to Albania. For example, Leka and his family illustrate the extent to which some participants were not able to fully comprehend living conditions and the lifestyle and relied on information from others, or the Albanian TV adverts, while in Greece as sources of information. Respondents were influenced by what was retrospectively viewed by them as misinformation from governmental sources.

Leka: We had bought one of these satellite TVs and they used to show adverts of Albania, displaying some of the best spots in Albania, somewhere in Saranda, some part from here [Tirana] and elsewhere. And Berisha [former Prime minister] used to say: "there will be no salaries under 50000 ALL [€370]". I used to tell my wife: "wait a minute, the prices are cheap there..., if we both get 50000 ALL, we are okay" (laughs). We will buy a house and a shop, we would do something. When we came here, we were like, oh my God, we found crap! (45 years, male, family case study, Tirana: wave 1).

Such narratives were obtained primarily from returnees from Greece, who were involved in informal work and were unable to visit Albania regularly. The involuntary nature of return led most respondents to view the return to Albania as a disruption to 
their migratory activities and future ambitions. In many cases, families had to become split across countries, with some members remaining in the destination country. This contributed to insecurities about family life which was often exacerbated by concerns about the extent to which children were, partly owing to language barriers, able to integrate successfully into the local community.

Although the return was sudden and unexpected for almost all returnees, mostly focus group discussions revealed that a smaller group of respondents, particularly migrants returning from Italy, described their return as being better planned. These participants tended to be more economically stable and had often been able to acquire citizenship rights in the previous country. They also had visited Albania on a more regular basis and appeared better prepared financially and in terms of the skills they had acquired while abroad (e.g. hairdressing or baking) that mitigated difficulties upon their return. They also tended to choose to settle in Tirana due to better perceived economic prospects and had typically established a small family-run enterprise. Some of these respondents had already planned to return in the future and the return had been accelerated as a result of the crisis.'

\section{Employment Consequences and Regrets of Returning}

Many respondents who had relocated to Tirana were originally from other Albanian cities and this presented its own challenges. They described being 'unfamiliar' with the way of life in Tirana and having little local knowledge of the employment opportunities, schools and desirable living areas. The primary concerns upon return centred on lack of employment chances, precarious employment conditions and lower average monthly salaries particularly in the manual labour sector in which most respondents had been working previously. This was particularly apparent among respondents who had worked in construction, as they referred to salaries being 'zero' in comparison to Greece.

Flori: If I compare the salaries here to the ones in Greece, here it's like nothing compared to there. Work and salaries are zero here! There, you could work four to five hours and the money was 20 times higher (...). Whoever works here in the private sector, they employ their own people. Even when I find some work, they do not provide me with social security. I receive no social security here at all, even though I work. (42 years, male, family case study, Tirana: wave 1).

Participants like Flori felt frustrated about limited possibilities in Albania and they tended to perceive their return as regressive. The unfavourable economic conditions in Albania and lack of employment yielded powerful narratives of regret concerning return decisions as they reported a deterioration in their quality of life. Younger respondents who were struggling to adapt to live back in Albania often compared themselves to people they had known prior to emigrating. As narrated by Eda below, non-migrant acquaintances had, during respondents' absence, taken full advantage of opportunities in Albania to pursue education, gain stable employment and develop effective social networks: 
Eda: I think, others here have moved forward and I have regressed. They have grabbed all the opportunities and I feel as though I have moved backwards, and I cannot catch [up with] them. I will find myself only if I go back. I don't think I will ever catch up with them. They have taken all the opportunities and are deeply rooted (...). Here you are like floating in the air (35 years, female, Fier: wave 1).

This narrative reflects the psychological consequences of unemployment, and, while such feelings of regret pervaded most of the interviews, they were particularly notable among women who faced particular dire employment opportunities. Having migrated at a young age, these respondents had to reconcile the fact that while they had been pursuing their migration objectives, the lives of those who had remained in Albania had moved forward in many ways: "We made a mistake by returning. We could have endured the difficulties, like others, we would make it somehow, like all others who stayed." (Sonila, 41 years, female, Tirana: wave 2).

\section{The Local Constraints}

In the current study, return migrants from Greece who had relocated in Fier reported more difficulties in finding employment and to utilise skills and employment acquired abroad. Among respondents interviewed in Fier, it was often the case that both partners within the same households were unemployed. These participants tended to view the local conditions as non-conducive to the economic activities they had hoped for.

Rudina: When we moved here, we had other intentions. My husband was a cook and we wanted to open a small family restaurant and work together. But because we couldn't do this, we are now both unemployed. We thought of renting a restaurant (...) but then we realised that in Fier the 'culture' of eating outside is not popular. We saw that the small restaurants could make little income, so for us, it wasn't advantageous (...), so we realized we could not progress in this direction. (38 years, female, Fier: wave 1).

Rudina had spent 2 years in Fier at the time of the interview and felt disempowered due to being economically inactive and unable to use the acquired skills during migration. Even though they had accumulated savings, some felt extremely constrained in terms of the ability to invest in small-scale enterprise. This is also illustrated by considering that participants' decisions to settle in the more economically disadvantaged city of Fier were often a result of financial constraints not permitting relocation to the more expensive capital.

Nonetheless, even those comparatively successful and involved in enterprises frequently lamented high taxation and voiced concerns about a lack of profitability. Individual stories and focus group discussions also highlight that political favouritism, corruption and lack of support from local authorities were viewed as insidious to virtually all aspects of public life and construed as significant impediments to accessing the labour market. As Mira (38 years, female, Tirana: wave 1) illustrates "You work here only if you are involved in politics or if you have 'connections'. Here it isn't about who is best suited for a position or about who deserves it". When asked whether they had received any assistance from the reintegration assistance programme developed by 
the Albanian government, none of the respondents was aware of such programs or had taken advantage of relevant policies.

In addition to employment difficulties, almost all returnees reported dissatisfaction with the welfare system and public services in the origin country. Responses to a question regarding future plans were compelling in that they consistently highlighted participants' inability to make long-term plans, regardless of the extent to which respondents viewed their return as being potentially sustainable or not. A climate of uncertainty and hopelessness for the future loomed profoundly in interviews and this elevated feelings of failure among returnees.

Eduart: There is no continuity here. You think that today you are heading in a particular direction and tomorrow the flow takes you to find yourself heading in another [direction]. There is no certainty! (...). Abroad you know that if you are in a job, you will work, and it will go on. You will progress and look to the future in the knowledge that you are likely to advance further. Here, it doesn't work like that. Here, they tell you "Go, it's not a problem...! We will get someone else and pay him half the salary I am paying you." (Male, 41 years, Tirana: wave 2).

As Eduart highlights, there was a perceived lack of continuity in Albania and the view that 'you cannot see far here' was frequently expressed when referring to the lack of a stable political and economic structure to provide employment security and mobility. Similarly, respondents engaged in entrepreneurship expressed concerns about the unstable economy and political climate which were seen to make it difficult to make plans or to make accurate business forecasts.

Return experiences led respondents to re-evaluate their migration experiences in light of the sacrifices they had made to pursue their goals abroad. In many cases, interviewees felt that they had worked exceptionally hard during their time in Greece and Italy at the expense of pursuing a more fulfilling work-life balance, as is illustrated emotively by Anita: "I would have lived better. In the morning, I drank that coffee and hastily ran to work..., if I had known what would happen, I would have sat and enjoyed it!" (42 years, female, Tirana: wave 1). This is an indication of the extent to which the return made respondents, like Anita, view migration as a process that, while geared towards achieving economic gains, came at the expense of social costs. Moreover, these feelings were heightened by frequent disparaging comments by others about why they had returned in the first place which reinforced respondents' feelings of 'double failure'. In other words, respondents expressed regret about both having left and also having returned.

\section{The Broader Social Context}

The stories and reflections shared in many interview responses reveal that interviewees' uncertainties not only encompassed economic concerns but extended to insecurities about family life and their children's prospects. With notable exceptions, for many respondents, the future appeared to be bleak, which was readily apparent in powerful narratives reflecting disidentification with their homeland that had come about as a result of their return being fraught with uncertainties and tension. Illustrating the extent 
to which such feelings of regret were intertwined with concerns for the wider family, Rudina, for example, comments:

Rudina: I have only the DNA with my family. Nothing else, nothing else. I feel sorry that I say this for my country. It's a beautiful country with cursed people. I am sorry to say this about my country, but it's a truth I face every day... So, 'to be attached to what?' (...) my country does not provide me with any opportunities. What kind of opportunities has my country provided me with? A job? The minimal thing..., I would work my guts out, I don't want money or social assistance... no. A working place. A future for my children. I don't see it here (38 years, female, Fier: wave 1).

Her narrative reflects the way life circumstances with the home country and a perceived lack of agency to alter conditions for herself and for her children impacted identification with Albania. Interviews and family case studies reflected an ongoing erosion or abandonment of 'patriotic sentiments' whereby migrants' narratives alternated between expressing both attachment to and disillusionment with Albania, in particular in relation to their children: "I wanted my children to be in the land of grandfathers and not be lost in a foreign country" to "nothing works here... if I could, tomorrow, I would take my children and go to another country." (Leka, 47 years, male, Tirana: wave 1).

Respondents who had spent a comparatively longer time abroad, particularly those returning from Greece, appeared more attached to their previous lifestyle, remained socially embedded in the host culture and identified more strongly with the Greek way of life. Unlike returnees who had worked in low-skilled work, such respondents tended to be comparatively better off economically and had often been able to acquire citizenship rights in the previous country. As such, they tended to be better able to retain transnational contact which shaped positively their post-return experiences. The capacity to retain meaningful relations with the previous country both ensured a sense of stability and embeddedness. Ongoing connections with the previous host country were also important economically as, for example, it enabled respondents to source products and equipment from these countries. As Anita remarked: "I have many friends there and the people I get the [hair] products from are Greeks. I travel there every month. I cannot live without Greece" (42 years, female, Tirana: wave 1). Such ties shaped positively the experiences of a small group of migrants from both Greece and Italy, as they could travel more often to the previous country and retained their strong identification with Italy or Greece.

\section{Transnational Immobility and Future Uncertainties}

When asked about their future plans and whether they wished to continue to live in Albania or re-migrate, the majority of respondents highlighted their return was not necessarily permanent. Indeed, the return during the economic crisis, for many, revived and reinforced preconceptions regarding the difficulties of building a future in Albania which they had held prior to initially migrating abroad. As focus group discussions revealed, in particular, respondents returning from Greece and those working in lowskilled jobs located both in Tirana and Fier frequently proclaimed that the situation was deteriorating and that they would reconsider emigrating again. 
Albi: If there is work in Greece, I would leave tomorrow. I see no green light here. Everything here is getting worse and worse. It's not a short period that will pass. It has always been like this. (40 years, male, Fier, wave 2).

It is noteworthy that considerations pertaining to the propensity to re-migrate almost exclusively centred on a possible return to Greece. Re-migration to Greece under difficult economic circumstances, for those respondents, appeared to be the only feasible choice due to the movement restrictions imposed on them by other Western European countries as well as due to many of them retaining Greek work permits. Overall, there was a strong sense of participants 'feeling stuck' in Albania both as a consequence of mobility restrictions and also as a result of the continued challenges the previous host economies were experiencing at the time the interviews were carried out. At the same time, respondents who, like Albi, worked in lower skilled jobs appeared to actively consider engaging in circular movements for seasonal work in Greece. This was not observed among migrants returning from Italy who had frequently started businesses and were trying to make those work.

The age of respondents also appeared to influence interviewees' propensity to re-migrate and shape their concerns about the future. Many respondents in the current study were in their forties and expressed a strong psychological need to anchor themselves in a place and establish a sense of permanency. They also expressed loathing with regard to the idea of being 're-immigrants' emphasising that "it takes guts to start [again] from the beginning" (Eduart, male, 41 years, Tirana: wave 2), particularly when moving abroad again was likely to involve the entire family. These examples both document the fluidity of respondents' current life circumstances and also indicate that life post-return is likely to evolve in different ways.

\section{Discussion and Conclusion}

In this paper, we have shown that unlike many types of return discussed in migration literature, return migration during times of economic downturn was associated with premature returns that were characterised by a lack of social and financial preparation prior to resettling. We showed that return circumstances as well as return experiences reflect multiple uncertainties caused by challenging socio-economic conditions in both destination and the origin country as well as by mobility restrictions to engage in further migration. Through an explicit focus on return migration, our findings show how uncertainty impacts return migrants' lives and plans for the future and contribute to the literature on international migration which has tended to examine the causes and experiences of return migration in the wake of the financial crisis (Bastia, 2011; Buckley, 2012; Bygnes and Erdal 2017; Zaiceva and Zimmermann 2016).

Findings indicate that for most of the respondents, the decision to return was undertaken in the face of economic adversity in that many had lost their jobs and were unable to survive financially in the previous destination country. Upon returning to Albania, the study further documents that, despite entrepreneurship activities, mirroring 
the wider return migration literature (Dustmann and Kirchkamp, 2002), many of the families interviewed continued to face unfavourable economic conditions such as lack of employment or low salaries. Our analysis suggests that returnees moving from Greece and particularly those who were located in Fier reported more difficulties and hindrances to successfully resettling in Albania. This group of migrants had tended to work in lower skilled jobs during migration and had been unable to migrate elsewhere and frequently found less employment chances upon returning. Findings of this study in the Albanian context therefore augment work which was conducted during this period and focussed on the economic hardship of returning migrants in the wake of the global financial crisis (e.g. Coniglio and Brzozowski, 2018; Spitzer and Piper, 2014). Our findings regarding the link between pre-return experiences and expectations as well as those post-return as important influences on post-return adaptation resonate with other research (Mähönen and Jasinskaja-Lahti 2012). In the current study, returnees with less realistic expectations, for example, tended to experience more frustration and disappointment upon their return. With many participating families in the current study living split lives (with members remaining behind) and having to deal with socio-economic challenges, findings also support calls for a more nuanced distinction between dominant binary 'voluntary' and 'involuntary' return categorizations (Van Houte et al. 2016). In this way, future research should be reflective of the complexities and the degree of volition involved in return migration decisions. This could have implications for informing the knowledge base with regard to how home countries offer reintegration assistance to return migrants.

The extent to which respondents' return had been prepared also emerged as a significant influence on return experiences. It was notable that while the degree of preparedness appeared to influence positively the life chances of some returnees (e.g. in terms of labour market adaptability), this was not uniform across all participants, the majority of which appeared to be psychologically and financially ill-prepared with insufficient resources to start a new life in Albania. Our findings are consistent with Cassarino (2004) of return migration which emphasises the dialectic interplay between preparedness (e.g. willingness/readiness to move and mobilisation of informational, finance and social resources) and local conditions (e.g. support from local authorities) encountered upon return in shaping the lives of return migrants. Narratives in the current study suggest that the structural and socio-economic conditions in Albania, for example, were not viewed as facilitating utilisation of the skills returnees had acquired during their migration and limited the extent to which they could invest in business opportunities. This is consistent with other researches indicating that local economic contexts do not always facilitate the conversion of capital and that immigrants can find it difficult to secure upward mobility vis-à-vis locals (Grigoryev and Berry 2017).

When contrasted with previous research documenting the relative success of returning from particular destination countries (e.g. Germany and Scandinavia; Coniglio and Brzozowski 2018), the current findings illustrate the downward mobility of returnees coming from less developed countries. In this way, the effects of different contexts in both destination and origin countries are important in shaping return trajectories.

The current study further documents how during the crisis return migrants were impacted psychologically by viewing their migration as incomplete and by their perceived inability to resettle successfully upon returning to Albania. Narratives 
reflected respondents' emotional turmoil and a discernible lack of identification with their homeland, which was viewed as a place not affording many opportunities for the future, was apparent. In the current study, however, the premature return and the current economic hardship appeared to override such emotions and tainted respondents' views of Albania as well as obscuring the extent to which they felt able to fulfil their aspirations. This may reflect ontological insecurity as a result of difficulties keeping their envisaged narrative 'going' (c.f., Giddens 1993: 54) considering that migrants were socio-culturally embedded in the host society (Tsuda, 1999). In the face of uncertainty, many respondents thus appeared unable to achieve equilibrium and continuity in their lives with respect to having an emotional attachment to Albania as this was obscured by the material and economic threats to their livelihood as well as regrets concerning 'double-failed journeys'.

The findings also highlight that a lack of satisfaction with the home country and continued affinity with the previous country (particularly for returnees from Greece) play a significant role in shaping their current sense of belonging. Respondents from this group identified more with the Greek way of life and this exacerbated 'fragmented identities' (Hedetoft 2004) upon return. This is similar to research suggesting that migrants can be made to feel different and experience social alienation in the home country (King, 2000; Ralph 2013; Werbner, 2011). Somewhat different from migrants simultaneously identifying with 'multiple homes' (Blunt and Dowling 2006), the current findings point to identities and belonging being reconstructed through an interplay between economic considerations, identification with the host society and how they are made to feel in the home country by others.

Findings also afford unique insights into the distinct features of returning from European Union to non-European Union countries. The current study, in this way, documents that experiences of (re)settlement reflect multiple uncertainties caused by socio-economic conditions in both Albania and the origin country as well as by mobility restrictions to engage in further migration. For participants who were economically unstable in Albania, particularly those coming from Greece, returning to Albania was not seen to necessarily be permanent and, depending on the Greek economy, many aspired to return to Greece. While many had desired to migrate to other European countries, this was not possible for most respondents as they had not obtained Greek or Italian citizenship. This contrasts with studies on intra-European migration during this period which document the extent to which migrants were better able to buffer some effects of the economic crisis by either remaining in the destination country, by migrating to other European destinations or by becoming circular migrants (Bygnes and Erdal, 2017; Zaiceva and Zimmermann, 2016). In line with this work, in the current study, respondents' migration journeys were also shaped profoundly by the economic downturn; however, the trajectories of their migration journeys were far less flexible and tended to be restricted to Albania which was associated with particular challenges to their life trajectories. In the current study, these macro-level movement restrictions were further mediated at the micro- and meso-levels by respondents' apprehensiveness to engage in further migration journeys at a life stage in which they felt a need to prioritise settling down. These movement restrictions and subjective sentiments therefore add contextual and psychological nuance to the well-documented notions of the mobility gap (Shamir 2005) which delineate the power geometries and hierarchies shaping transnational relations and migratory movements (King 2012: 144). 
A number of limitations need to be borne in mind when considering the current findings. While recruitment from two sites may have helped with regard to the extent to which findings can be generalised to different settings, the overall sample of the current study was small and snowball sampling was used to identify respondents. This limits the extent to which findings may be generalisable to other populations and it also needs to be noted that the profile of return migrants to Albania is heterogeneous (GarcíaPereiro, 2019). Furthermore, as current findings indicate, the experiences of return are shaped by interrelated challenges with regard to those brought on by the economic crisis as well as those associated with the return. This means that it was not always possible to discern the relative influence of different factors and future research examining return migration in similar economically challenging conditions needs to be sensitive to how these interact. Establishing representative longitudinal cohorts of (return) migrants could be a means of foregrounding the longer term outcomes and how different factors impact each other. It would also be prudent for research in this area to make use of other data sources as the current study relied on self-report.

In conclusion, the current study contributes to our understanding of causes and consequences of return migration during particularly challenging times. It highlights that returning under exceptional circumstances of an economic crisis interrupts migrant family plans and impedes individuals' ability to navigate challenges successfully upon returning. Findings illustrate varied and uneven post-return experiences, with those who were better prepared being more capable of transferring human capital to the country of origin and better able to engage in transnational mobility with the destination country. Such transnational practices were, however, constrained by return migrants to migrate to other EU destinations. Overall, the findings document the considerable pressures return migrants experience with regard to managing the effects of economic difficulties, and detail how these interact with previous experiences and current support to shape profoundly their capacity to reintegrate.

\section{Declarations}

Conflict of Interest The authors declare no competing interests.

Open Access This article is licensed under a Creative Commons Attribution 4.0 International License, which permits use, sharing, adaptation, distribution and reproduction in any medium or format, as long as you give appropriate credit to the original author(s) and the source, provide a link to the Creative Commons licence, and indicate if changes were made. The images or other third party material in this article are included in the article's Creative Commons licence, unless indicated otherwise in a credit line to the material. If material is not included in the article's Creative Commons licence and your intended use is not permitted by statutory regulation or exceeds the permitted use, you will need to obtain permission directly from the copyright holder. To view a copy of this licence, visit http://creativecommons.org/licenses/by/4.0/.

\section{References}

Adamczyk, A. (2016). Albanian immigrants in Greece: From unwanted to tolerated? Journal of Liberty and International Affairs, 2(1), 49-59 https://nbn-resolving.org/urn:nbn:de:0168-ssoar-47088-8. 
Aycan, Z., \& Berry, J. W. (1996). Impact of employment-related experiences on immigrants' psychological well-being and adaptation to Canada. Canadian Journal of Behavioural Science, 28(3), 240-251. https:// doi.org/10.1037/0008-400X.28.3.240.

Bamberg, M. (2012). Narrative analysis. In H. Cooper (Ed.), APA handbook of research methods in psychology. The American Psychological Association (pp. 77-94).

Barjaba, J. (2018). Exploring transnational entrepreneurship among Albanian migrants and returnees. $\mathrm{PhD}$ Thesis. School of Global Studies. University of Sussex.

Barjaba, K., \& King, R. (2005). Introducing and theorizing Albanian migration. In R. King, N. Mai, \& S. Schwandner-Sievers (Eds.), The new Albanian migration. Brighton.

Baser, B., \& Toivanen, M. (2019). Diasporic homecomings to Kurdistan Region of Iraq: Pre- and post-return experiences shaping motivations to return. Ethnicities, 1-24.

Bastia, T. (2011). Policy arena: Should I stay or should I go? Return migration in times of crises, Journal of International Development, 23, 583-595.

Beets, G., \& Willekens, F. (2009). The global economic crisis and international migration: An uncertain outlook. Vienna Yearbook of Population Research, 7, 19-37.

Bijwaard, G. E. (2010). Immigrant migration dynamics model for The Netherlands. Journal of Population Economics., 23, 1213-1247.

Bijwaard, G. E., \& Wahba, J. (2019). Immigrants' wage growth and selective out- migration. Oxford Bulletin of Economics and Statistics, 81(5), 1065-1094.

Black, R., \& Castaldo, A. (2009). Return migration and entrepreneurship in Ghana and Cote D'ivoire. The role of capital transfers, $100(1), 44-58$.

Blunt, A., \& Dowling, R. (2006). Home. Routledge.

Borjas, G., \& Bratsberg, B. (1996). Who leaves? The outmigration of the foreign-born. The Review of Economics and Statistics, 78(1), 165-176.

BTI (2014) (Bertelsmann Stiftung) - Albania Country Report. Gütersloh: Bertelsmann Stiftung. http://www. bti-project.org/

Buckley, M. (2012). From Kerala to Dubai and back again: Construction migrants and the global economic crisis. Geoforum, 43(2), 250-259.

Bygnes, S., \& Erdal, M. B. (2017). Liquid migration, grounded lives: Considerations about future mobility and settlement among Polish and Spanish migrants in Norway. Journal of Ethnic and Migration Studies, 43(1), 102-118.

Caponio, T., \& Cappiali, T. M. (2018). Italian migration policies in times of crisis: The policy gap reconsidered. South European Society and Politics, 23(1), 115-132.

Carletto, C., Davies, B., Stampini, M., \& Zezza, A. (2006). A country on the move: International migration in post-communist Albania. International Migration Review, 40(4), 767-785. https://doi.org/10.1111/j. 1747-7379.2006.00043.x.

Cassarino, J. P. (2004). Theorizing return migration: The conceptual approach to return migrants revisited. International Journal on Multicultural Societies, 6(2), 253-279.

Cassarino, J. P. (2008). Conditions of return migrants. International Journal on Multicultural Societies, 10(2), 95-105.

Cavounidis, J. (2018). Migration and the economic and social landscape of Greece. South-eastern European Journal of Economics, 1, 59-78.

Cena, E., Heim, D., \& Trandafoiu, R. (2018). Changing places: Children of return migrants in Albania and their quest to belong. Journal of Ethnic and Migration Studies, 44(7), 1156-1176.

Coniglio, N. D., \& Brzozowski, J. (2018). Migration and development at home: Bitter or sweet return? Evidence from Poland. European Urban and Regional Studies, 25(1), 85-105.

Constant, A., \& Massey, D. S. (2002). Return migration by German guest workers. Neoclassical versus New Economic theories. International Migration., 40(4), 5-38.

De Bree, J., Davids, T., \& De Haas, H. (2010). Post-return experiences and transnational belonging of return migrants: A Dutch-Moroccan case study. Global Networks, 10(4), 489-509.

De Haas, H. (2005). International migration, remittances and development: Myths and facts. Third World Quarterly, 26(8), 1269-1284 Retrieved May 26, 2020, from www.jstor.org/stable/4017714.

De Haas, H., \& Fokkema, T. (2011). The effects of integration and transnational ties on international return migration intentions. Demographic Research, 25(24), 755-782.

Dustmann, C., \& Kirchkamp, O. (2002). The optimal migration duration and activity choice after re-migration. Journal of Development Economics., 67(2), 351-372.

Duval, D. T. (2004). Linking return visits and return migration among Commonwealth Eastern Caribbean migrants in Toronto. Global Networks: A Journal of Transnational Affairs, 4(1), 51-67. 
Earthy, S., \& Cronin, A. (2008). Narrative analysis. In N. Gilbert (Ed.), Researching Social Life. (420-439). Sage.

Faist, T. (2008). Migrants as transnational development agents: An inquiry into the newest round of the migration-development nexus. International Migration, 14(1), 21-42.

García-Pereiro, T. (2019). Clustering reasons for returning: An overview of return migration in Albania. International Migration \& Integration, 20, 61-374.

Gemi, E. (2014). Transnational practices of Albanian families during the Greek crisis: Unemployment, deregularization and return. International Review of Sociology, 24(3), 406-421.

Germenji, E., \& Milo, L. (2009). Return and labour status at home: Evidence from returnees in Albania. Journal of Southeast European and Black Sea Studies, 9(4), 497-517.

Grabowska, I., \& Jastrzebowska, A. (2019). The impact of migration on human capacities of two generations of Poles: The interplay of the individual and the social in human capital approaches. Journal of Ethnic Migration. Studies. https://doi.org/10.1080/1369183X.2019.1679414.

Grigoryev, D., \& Berry, J. W. (2017). Acculturation preferences, ethnic and religious identification and the socio-economic adaptation of Russian-speaking immigrants in Belgium. Journal of Intercultural Communication Research, 46(6), 537-557. https://doi.org/10.1080/17475759.2017.1386122.

Groenewold, G., \& De Valk, H. A. G. (2017). Acculturation style, transnational behaviour, and returnmigration intentions of the Turkish second generation: Exploring linkages. Demographic Research, 37, 1707-1734. https://doi.org/10.4054/demres.2017.37.53.

Hagan, J. M., \& Wassink, J. T. (2020). Return migration around the world: An integrated agenda for future research. Annual Review of Sociology, 46, 1-20.

Hausman, R., \& Nedelkoska, L. (2018). Welcome home in a crisis: Effects of return migration on the nonmigrants' wages and employment. European Economic Review, 101, 101-132.

Hedetoft, U. (2004). Discourses and images of belonging: Migrants between 'new racism', liberal nationalism and globalization. AMID Working Paper Series 5.

INSTAT \& IOM. (2013). Return migration and reintegration in Albania. Institute of Statistics and International Organization for Migration https://albania.iom.int/sites/default/files/publication/15.\% 20Return\%20Migration\%20and\%20Reintegration\%20in\%20Albania\%202013.pdf. Accessed 16 January, 2016.

IOM (2009). The impact of financial crises on international migration: Lessons learned. IOM Migration Research Series. No 37. International Migration Organisation.

Itzigsohn, J., \& Saucedo, S. G. (2002). Immigrant incorporation and sociocultural transnationalism. International Migration Review, 36(3), 766-799.

Kilic, T., Carletto, C., Davis, B., \& Zezza, A. (2009). Investing back home: Return migration and business ownership in Albania. Economics of Transition, 17(3), 587-623.

King, R. (2000). Generalizations from the history of return migration. In R. King (Ed.), Return migration: Journey of hope or despair? (pp. 7-55). International Organization for Migration.

King, R. (2007). Albania as a laboratory for the study of migration and development. Journal of Southern Europe and the Balkans, 7(2), 133-155.

King, R. (2012). Geography and migration studies: Retrospect and prospect. Population, Space and Place, 18 , $134-253$.

Koser, K., \& Kuschminder, K. (2015). Comparative research on the assisted voluntary return and reintegration of migrants. IOM.

Kule, D., Macellari, A., Papapanagos, S., \& Sanfey, P. (1999). The causes and consequences of Albanian emigration during transition: Evidence from micro- data. Working paper no. 46. London: European Bank for Reconstruction and Development

Lafleur, J.-M., \& Stanek, M. (2016). South-north migration of EU citizens in times of Crisis. Springer Open.

Levitt, P. (1998). Social remittances: Migration driven local-level forms of cultural diffusion. International Migration Review, 34, 926-948.

Lyberaki, A., \& Maroukis, T. (2005). Albanian immigrants in Athens: New survey evidence on employment and integration. Southeast European and Black Sea Studies, 5(1), 21-48.

Mähönen, T. A., \& Jasinskaja-Lahti, I. (2012). Acculturation expectations and experiences as predictors of ethnic migrants' psychological well-being. Journal of Cross-Cultural Psychology, 44(5), 786-806. https://doi.org/10.1177/0022022112466699.

Maroukis, T., Gemi, E., (2011). Circular migration between Greece and Albania: A case study, METOIKOS project: Circular migration patterns in Southern and Central Eastern Europe: Challenges and opportunities for migrants and policy makers, European University Institute.

Mayer, S. D., Harima, A., \& Freiling, J. (2015). Network benefits for Ghanaian diaspora and returnee entrepreneurs. Entrepreneurial Business and Economics Review, 3(3), 95-122. 
McCormick, B., \& Wahba, J. (2001). Overseas work experience, savings and entrepreneurship amongst return migrants to LDCs. Scottish Journal of Political Economy, 48(2), 164-178.

Piracha, M., \& Vadean, F. (2010). Return migration and occupational choice: Evidence from Albania. World Development, 38(8), 1141-1155.

Pojani, D. (2010). Tirana: City profile. Cities Journal, 27(6), 483-495.

Portes, A., Guarnizo, L., \& Landolt, P. (1999). Transnational communities. Routledge.

Ralph, D. (2013). Managing sameness and difference: The politics of belonging among Irish-born return migrants from the United States. Social and Cultural Geography., 13(5), 445-460.

Reynolds, T. (2008). Ties that bind: Families, social capital and second-generation return migration. Sussex Centre for Migration Research Working Paper, 46.

Shamir, R. (2005). Without borders? Notes on globalization as a mobility regime. Sociological Theory, 22(2), 197-217.

Sinatti, G. (2018). Return migration, entrepreneurship and development: Contrasting the economic growth perspective of Senegal's diaspora policy through a migrant-centred approach. African Studies, 10, 1-15.

Sjaasaad, L. A. (1962). The costs and returns of human migration. Journal of Political Economy, 70, 80-93.

Spitzer, D., \& Piper, N. (2014). Retrenched and returned: Filipino migrant workers during times of crisis. Sociology, 48(5), 1007-1023.

Triandafyllidou, A. \& Lazarescu, D. (2009) The impact of the recent global economic crisis on migration. Preliminary insights from the south eastern borders of the EU (Greece) [Online] Available from: http:// cadmus.eui.eu/bitstream/handle/1814/12995/CARIM_ASN_2009_40.pdf?sequenc e=1\&isAllowed=y [Accessed: 20 March 2021]

Triandafyllidou, A., Dimiatri, A., Maroufof, M., Hatziprokopiou, P., Gemi, E., Nikolova, M., \& Yousef, K. (2013). Migration in Greece: People, policies and practices. IRMA Paper.

Tsuda, T. (1999). The permanence of "temporary" migration: The "structural embeddedness" of JapaneseBrazilian immigrant workers in Japan. Journal of Asian Studies, 58(3), 687-722.

UNDP. (2016). Human development report. UNDP.

van Houte, M., Siegel, M., \& Davids, T. (2015). Return to Afghanistan: Migration as reinforcement of socioeconomic stratification. Population, Space and Place, 21(8), 692-703.

van Houte, M., Siegel, M., \& Davids, T. (2016). Deconstructing the meaning and motivations for return: An Afghan case study. Comparative migration studies, 4(21), 1-17.

van Meeteren, M., Engbersen, G., Snel, E., \& Faber, M. (2014). Understanding different post-return experiences. The role of preparedness return motives and family expectations for returned migrants in Morocco, Comparative Migration Studies, 2(3), 335-360.

Vullnetari, J. (2013). Albania on the move: Links between internal and international migration. Amsterdam University Press.

Wang, Z., \& Yang, W. (2013). Self-employment or wage-employment? China Agricultural Economic Review, 5(2), 231-247.

Werbner, P. (2011). Mothers and daughters in historical perspective: Home, identity, and double consciousness in British Pakistanis' migration and return. Journal of Historical Sociology, 26(1), 41-61.

Yijälä, A., \& Luoma, T. (2019). The importance of employment in the acculturation process of well-educated iraqis in Finland: A qualitative follow-up study. Refugee Survey Quarterly, 38(3), 314-340.

Zaiceva, A., \& Zimmermann, K. F. (2016). Returning home at times of trouble? Return migration of EU enlargement migrants during the crisis. In M. Kahanec \& K. F. Zimmermann (Eds.), Labor migration, EU enlargement, and the great recession. Springer.

Publisher's Note Springer Nature remains neutral with regard to jurisdictional claims in published maps and institutional affiliations. 